\title{
UM VÔMITO DE MELANCOLIAS GARGALHADAS
}

Recebido: 27/01/2021

Aprovado: 21/06/2021

DOI: $10.18817 /$ rlj.v5i01.2489

Publicado: $30 / 07 / 2021$

Hêmille Raquel Santos Perdigão ${ }^{1}$ Orcid ID: https://orcid.org/0000-0002-7832-5572

MORENO, Newton. História que alguém me contou. São Paulo: Ilustríssima, Folha de São Paulo, 2011.

O conto História que alguém me contou, de Newton Moreno, é a narrativa, do ponto de vista de um passageiro, de um episódio ocorrido em um metrô. O conto começa in medias res, com a frase "Uma negra bêbada tropeçou para dentro do metrô". Tem-se a impressão de que o texto não apresentará nenhum acontecimento extraordinário, visto que a entrada de uma pessoa bêbada em um metrô é um fato corriqueiro. Cortàzar, em sua obra crítica, defende que, no início de um conto, é improvável que sejam encontrados "elementos gratuitos, meramente decorativos". (CORTÁZAR, 1998). Percebe-se que no conto de Moreno não há detalhamentos do cenário e dos personagens, de modo que o que consta no texto é o indispensável para a compreensão.

A aparente ausência de informações é característica do gênero conto literário, o que leva Cortàzar a comparar a função do contista à do fotógrafo, pela comum necessidade de

escolher e a limitar uma imagem ou um acontecimento que sejam significativos, que não apenas tenham valor em sim mesmos, mas que sejam capazes de funcionar no espectador ou no leitor como uma espécie de abertura, de fermento que projeta a inteligência e a sensibilidade em direção a algo que chega muito mais longe do que o episódio visual ou literário contidos na foto ou no conto. (CORTÁZAR, 1998).

A capacidade do conto de apontar para algo além do episódio narrado é notável nas frases seguintes à anunciação da entrada da negra: "Testou seus superpoderes, tentando se equilibrar com o vagão em movimento. Parecia surfar no ar já contaminado de seu bafo". (MORENO, 2011). O termo "superpoderes"

\footnotetext{
1 Bacharela em Letras: Estudos Literários pela Universidade Federal de Ouro Preto (UFOP). Mestranda em Letras: Estudos da Linguagem pela mesma universidade com financiamento da CAPES. E-mail: hemilleperdigao@gmail.com
} 
mostra a comicidade irônica com que a negra é analisada pelo narrador, mas, ao mesmo tempo, os verbos "equilibrar" e "surfar" remetem a um meio de locomoção marítimo e não ferroviário, em uma prévia de algo que será revelado posteriormente.

O narrador destaca, então, a alegria da mulher por se manter em pé, e deixa bem claro que suas gargalhadas causam incômodo a ponto de todos desejarem sua queda. Apesar da ausência de especificações de horário, imagina-se que o episódio se passa em um fim de horário comercial, quando a maioria dos passageiros são trabalhadores cansados, retornando para casa. A queda da mulher seria, para eles, um episódio cômico para entretenimento do entediante e demorado retorno; quiçá, seria o único fato cômico do dia. Além disso, havia um ódio por pensarem que, enquanto trabalhavam, a negra estava em um momento de lazer, tomando cervejas. Diante disso, o desejo de queda era, também, uma vontade de que ela fosse punida por estar se divertindo enquanto tantos trabalhavam. Todavia, ela não cai; ao contrário, se senta e começa a tagarelar, até que vomita.

O episódio da negra vomitando é algo vulgar. Seria o que Cortàzar chama de elemento significativo do conto, que marca a capacidade do autor de "transformar um vulgar episódio [...] no resumo implacável de determinada condição humana" (CORTÀZAR, 1998). Após a negra vomitar, todos se afastam para o outro lado do vagão, deixando-a sozinha. O vômito estabelece, assim, uma separação espacial ela e os demais passageiros e, por mais vulgar que seja o acontecimento, resume a condição humana de uma pessoa ser apartada das demais quando se livra do que lhe causava mal. O vômito é resultante de um desconforto interno e, caso não ocorra, causa um mal maior ao organismo, por um tempo prolongado. Ao vomitar, a pessoa elimina de si o que não foi digerido e dá início à sua recuperação. O que não havia sido digerido pela negra vem logo a seguir. Curiosamente, o afastamento consequente do seu vômito colocara os demais passageiros na condição de plateia. Ela entoa um canto, seguido de um conto popular. A história é de um africano que se passou por mulher para que ele, ao invés da amada, fosse levado embora de sua terra. A negra conta das más condições do transporte dos seus antepassados no navio e menciona que o negro, protagonista da história, não sorriu desde que deixou seu lar. Isso explica o porquê de a mulher gargalhar 
enquanto se equilibrava no transporte: estava gargalhando por todos os negros que deixaram de sorrir. Anos depois, o negro voltou à África para procurar sua mulher, mas teve a notícia de que ela havia tomado um navio à procura dele, viagem na qual sua vida chegou ao fim.

Como é próprio de um conto popular, a narrativa é passível de modificações, de modo que a performance da contadora é importante. No caso, as sentenças truncadas da negra transmitem sua tristeza, que faz com que seja difícil tratar do assunto. Para a maioria das pessoas no vagão, a viagem representava o retorno à família, enquanto para a mulher negra, ao contrário, remetia à separação das famílias de seus antepassados. Com isso, o conto popular marca, no conto literário, uma mudança de efeito, do cômico para o melancólico. Aparentemente, Moreno está em acordo com Poe que "a melancolia é, assim, o mais legítimo de todos os tons poéticos." (POE, 1965, p. 914).

Também em acordo com o que Poe explica em sua Filosofia da Composição, Moreno considerou, em sua composição do conto, o efeito que causaria. (POE, 1965, p. 911). Ao inserir um conto popular em seu conto literário, Moreno conseguiu mostrar o efeito que ambos os gêneros podem causar: a melancolia do conto popular causou, nos personagens/passageiros do metrô, o mesmo efeito que a tensão entre o cômico e o melancólico no conto literário causou em nós, leitores: a reflexão sobre a melancolia mal digerida, que é vomitada em tantas gargalhadas que nos incomodam.

\section{Referências}

CORTÁZAR, Julio. Obra crítica. Tradução de Paulina Wacht e Ari Roitman. Rio de Janeiro: Civilização Brasileira, 1998

POE, Edgar Allan. Ficção Completa, Poesia e Ensaios. Tradução de Oscar Mendes. Rio de Janeiro: Companhia Aguilar Editora, 1965. 